\title{
炭素鋼及びステンレス鋼の冷間鍛造における 圧縮変形抵抗特性
}

\section{Compressive Flow Stress Characteristics of Carbon Steels and Stainless Steels during Cold Forging}

Kazunari ShInagawa, Takashi IshiKawa and Yuzo HosoI

\begin{abstract}
Synopsis :
Flow stress-strain curves of material are necessary in numerical analysis, such as finite element analysis, of cold forging process. The behaviors of compressive flow stress-strain in carbon steels and stainless steels at various temperature in the range of cold forming are studied by static and dynamic upsetting tests. In the experiments, the stress-strain of feritic stainless steel shows similar curves with that of carbon steel in the temperature range from 30 to $200^{\circ} \mathrm{C}$. Work-hardening behavior of austenitic stainless steel is more significantly affected by deformation temperature than those of carbon and feritic stainless. From the results of experiments, the flow stress is formularized as a function of strain, strain rate and temperature. The validity of this equation is examined through the comparison between load measured in upsetting test and that obtained by numerical simulation.
\end{abstract}

Key words : flow stress ; cold forging ; carbon steel ; stainless steel ; numerical analysis.

\section{1. 緒}

言

冷間鉔造は，近年急速に利用範囲が拡大しており，よ り複雑な製品形状への適用あるいは精密鍛造に代表され るような製㣍に対するより高い寸法精度が要求され，ま た，時代の流れとして，多品種少量生産を課せられるよ うになってきた。それに伴い, 工具設計の手間とコスト を省くため, 近年, CADの一環として有限要素法によ る数值解析手法を利用して, 加工中の変形過程を理論的 に解明しようとする多数の試みがなされてきている1). その際材料の特性を表す変形抵抗のデータが必要とな る.

このデータシートを作成するときには次のようなこと に留意しなければならない. 油压プレス等の低速な材料 試験機を用いた準静的な加工では素材内の塑性仕事に よって発生する熱は放散してしまい，素材自身はほとん ど温度上昇しない。それに対し，実際の生産現場では， 加工速度が速く, 高歪み域まで連続的に変形されるので, 変形抵抗は歪み速度に依存して増加するとともに，素材 内部での熱の蓄積による温度上昇のための軟化が起こる ことになる．従ってこのような実加工条件下での解析で
用いる変形抵抗には, 歪み, 歪み速度, 温度の影響が考 慮されていなくてはならない.

しかし，これまでの多くの研究では，測定された忍力 一歪み曲線が低歪み速度で低歪みの範囲であったり2), 高歪み速度の場合でも温度状態は試験温度の初期值だけ 示されているだけで不明瞭であったりする ${ }^{3)}$.このよう な中で最近，高温で，高歪み域まで測定可能な小坂田ら の提案した端面拘束压縮法 ${ }^{4) 5)}$ を利用し，各種鋼材の データシートを作成する共同作業が進行中である ${ }^{6)}$. し かし，これは扫もに炭素鋼のデータであり，ステンレス 鋼についての測定例はほとんどない.ここで，炭素鋼， フェライトステンレス鋼，オーステナイトステンレス鋼 を考えると，これらは結晶構造，組織，化学成分などの 違いから, 変形抵抗の歪み硬化性や温度依存性が大きく 異なっていると考えられる.そこで本研究では, これら の鋼種について冷間の温度範囲で試験温度を変えて, 油 圧プレスを用いた静的据込み試験と，機械プレスを用い た動的据込み試験を行い, 変形抵抗を測定し,これらの 鋼種の応力-歪み曲線に及ぼす温度の影響を調べた。そ して，冷間鍛造過程の数值解析にただちに適用できるよ うそれぞれの変形抵抗式を定めた。また，これらの変形

昭和 62 年 4 月本会講演大会にて発表 昭和 63 年 12月 12 日受付 (Received Dec. 12, 1988)

* 名古屋大学大学院 (Graduate School, Nagoya University, Furo-cho Chikusa-ku Nagoya 464)

*2 名古屋大学工学部 I博 (Faculty of Engineering, Nagoya University) 
抵抗式を剛塑性有限要素法 (FEM) と差分法 (FDM) を用いた変形と熱伝導を連成させた据込み加工の解析? に組み込み，加工荷重の推算を行い，それと本実験で得 られている荷重との整合性も確かめた。

\section{2. 実 験 方 法}

\section{$2 \cdot 1$ 供試材}

供試材は, 炭素鋼として C 1 材（機械構造用炭素鋼 S35C), C 2 材 (冷間压造用炭素鋼 SWRCH15A), フェ ライトステンレス鋼として F 1, F 2 材, オーステナイ トステンレス鋼としてA1 材（SUS316），A2 材を用 いた，化学組成を Table 1 に示す．F1は熱開鉎造した 丸棒状の材料を $900^{\circ} \mathrm{C}, 1 \mathrm{~h}$ 溶体化処理した，F 2 は熱 間压延した材料を， $1300^{\circ} \mathrm{C} ， 0.5 \mathrm{~h}$ でフェライト単相化 し水冷した．A 2 材は熱間鍛造した丸棒状の材料を $1000^{\circ} \mathrm{C}, 0.5 \mathrm{~h}$ 溶体化处理した. 熱处理後, いずれの試 料も直径 $\phi 11.2 \mathrm{~mm}$, 高さ $16.8 \mathrm{~mm}$ の円柱状試片 (高さ/ 直径=1.5）に機械加工した.

\section{$2 \cdot 2$ 試験法}

据込み試験は高温，高速度でも適用できる，日本塑性 加工学会推奖による端面拘束圧縮法45) に基づいて行っ た。この方法は冷間据込み試験用I具として基準となっ ている同心円溝付き耐压板を用いて，(高さ)/(直径) $=1.5$ の試験片を压縮し，その時の荷重と压下率の測定 值を，あらかじめ解析で得られている荷重一心力，压下 率-歪みの関係を利用して忘力-歪みの関係に変換するも のである.

\section{$2 \cdot 3$ 実験装置および実験条件}

静的据込み試験では, 容量 $300 \mathrm{tf}$ の油圧式圧縮試験 機を用い，据込み速度は変形熱による温度上昇が起こら

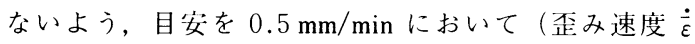
$=10^{-3} \mathrm{~s}^{-1}$ 程度) ほぼ一定速度になるようにした。試 片の加熱は，圧板の側壁画に市販のマントルヒーターを 巻き付け，その間にはさんで压板からの熱伝導を利用し て加熱した，その際試片側面に熱電対を付け，それによ り試験温度を調節して試験を行った。加熱には $5 \mathrm{~min}$ 程 度, 加Iに $10 \mathrm{~min}$ 程度かかり, 加I.中は $\pm 2{ }^{\circ} \mathrm{C}$ の範囲 で等温を保った。試験温度は窑温, $50^{\circ} \mathrm{C}$ から, $350^{\circ} \mathrm{C}$
まで $50^{\circ} \mathrm{C}$ ごとに変えた．変位の測定はオンラインダイ ヤルゲージで，荷重の測定はプレスラム下面にロードセ ルを装着して行った。

動的据込み試験では, 容量 $110 \mathrm{tf}$, 每分のストローク 数が 50 s.p.m.のクランクプレス（初期歪み速度 $\dot{\bar{\varepsilon}}=$ $15 \mathrm{~s}^{-1}$ 程度）を用いた。試片の加熱は静的据込み試験 と同様である。試験初期温度は窒温, $50^{\circ} \mathrm{C}$ から $300^{\circ} \mathrm{C}$ まで $50^{\circ} \mathrm{C} こ ゙ と に$ 変えた。変位の測定は渦電流式非接触 変位計を用い, 荷重はロードセルを用いてそれぞれの信 号を $\mathrm{A} / \mathrm{D}$ 変換器を通してコンピューターに取り込む高 速サンプリングシステムを用いて行った。試片はそれぞ れの試験で約 70\%まで圧縮加工した。

\section{3. 実 験 結 果}

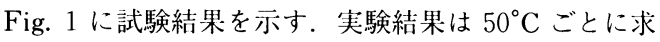

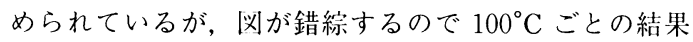
を示した，動的試験では歪み速度が大きいため, 変形抵 抗は静的試験で得られるものより高くなっている.また, 静的試験においては試片の塑性仕事による発熱は試験速 度が遅いため刻々工具側に流出するので, 心力-歪み曲 線に扮ける温度状態は一资であるが, 動的試験の場合は 試験速度が速いため発生熱が試片内に蓄積し, 各温度と も初期温度より上昇している。 そのため高歪みになるに したがい，見かけ上，歪み硬化が小さくなりむしろ軟化 しているようにみえる。この動的試験における加工にと もなう軟化の程度は炭素鋼はあまり大きくなく, 変形抵 抗はわずかに低下していくだけであるが，フェライト鋼 の場合は程度が大きく、特に等㴓での変形抵抗は一度 ピークをむかえてから大きく軟化している，また，オー ステナイト鋼の場合は，低歪み域では静的試験の場合と 同様加工硬化が大きいが歪みが大きくなると加工硬化が 急激に弱まり，変形抵抗はほほ一定になる。

\section{4. 考察}

\section{$4 \cdot 1$ 動的据込み試験における温度上昇の予想および変 形抵抗-歪み-温度の 3 次元表示}

静的試験で得られた変形抵抗曲線をフェライトステン レス鋼を例にとって変形抵抗一歪み-温度の 3 次元表示を

Table 1. Chemical compositions (wt \%).

\begin{tabular}{|c|c|c|c|c|c|c|c|c|c|}
\hline Steel & $\mathrm{C}$ & $\mathrm{Si}$ & Mn & $\mathrm{P}$ & $\mathrm{S}$ & $\mathrm{Ni}$ & $\mathrm{Cr}$ & Mo & $\mathrm{Al}$ \\
\hline C 1 (S35C) & 0.35 & 0.19 & 0.66 & 0.019 & 0.016 & - & - & - & 0.023 \\
\hline $\begin{array}{l}\text { C } 2 \text { (SWRCH15A) } \\
\text { F1 }\end{array}$ & $\begin{array}{l}0.16 \\
0.004\end{array}$ & $\begin{array}{l}0.06 \\
0.01\end{array}$ & $\begin{array}{l}0.71 \\
0.01\end{array}$ & $\begin{array}{l}0.015 \\
0.001\end{array}$ & 0.012 & 5.18 & 35.35 & $\overline{0} 01$ & 0.020 \\
\hline F 2 & - & $<0.05$ & $<0.01$ & 0.001 & 0.001 & 6.90 & $\begin{array}{l}35.35 \\
23.92\end{array}$ & 0.01 & $\begin{array}{l}0.032 \\
0.010\end{array}$ \\
\hline A 1 (SUS316) & 0.035 & 0.48 & 1.07 & 0.024 & 0.001 & 12.05 & 17.36 & 2.40 & \\
\hline A 2 & 0.003 & 0.03 & 0.016 & 0.001 & 0.001 & 16.96 & 23.15 & $<0.01$ & 0.047 \\
\hline
\end{tabular}



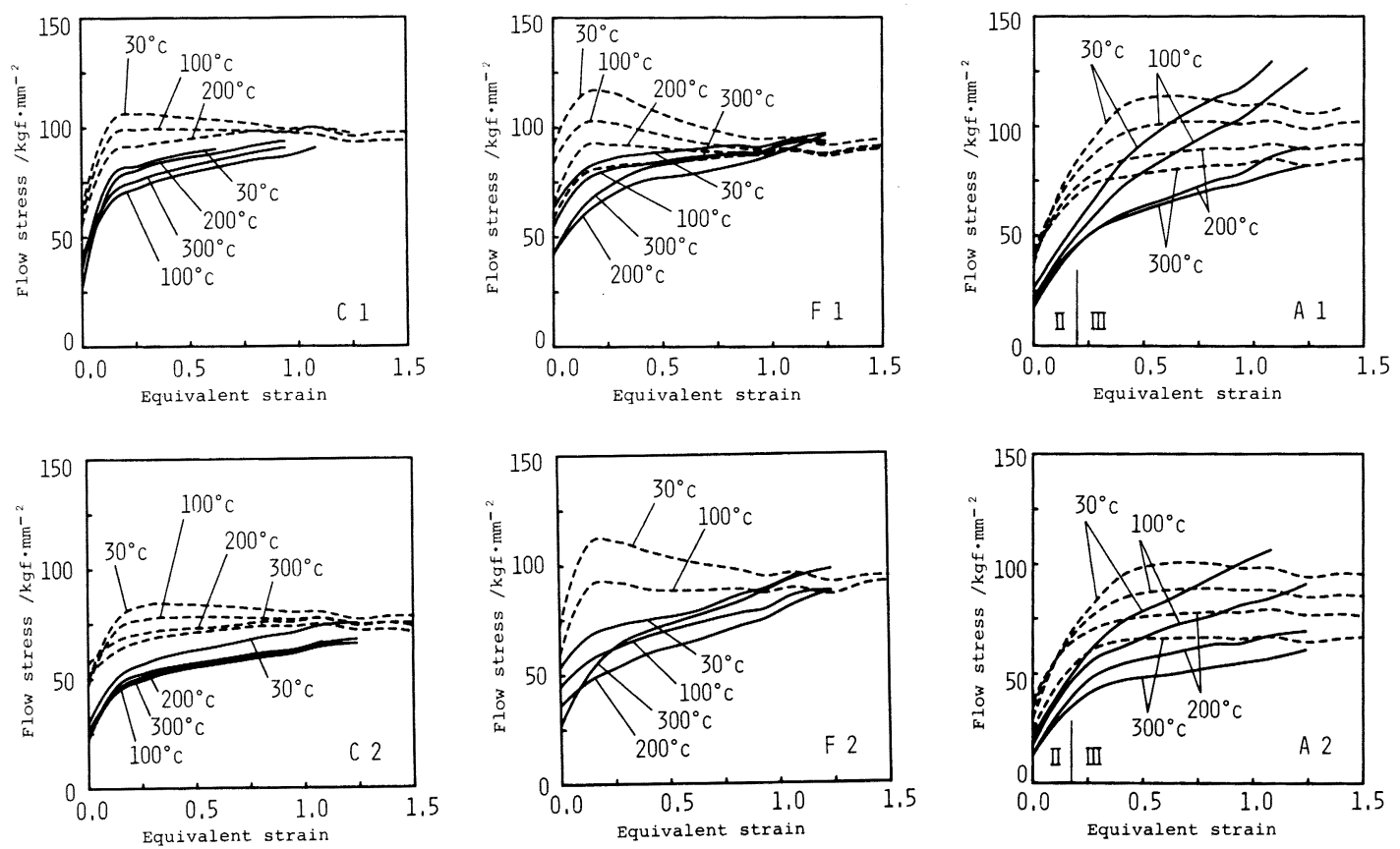

Fig. 1. Flow stress-strain curves at each test temperature by hydraulic press (solid lines) and mechanical press (broken lines).
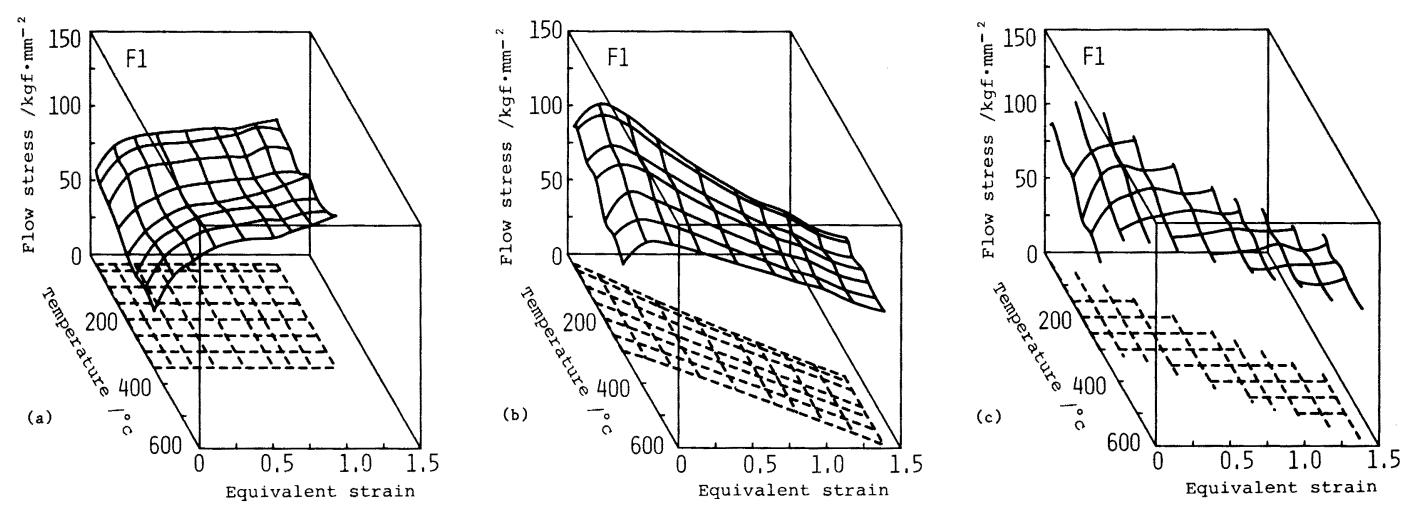

Fig. 2. Flow stress-strain curves (a) at various temperature by hydraulic press, (b) corrected by temperature rise by mechanical press and (c) modified at an interval of $50^{\circ} \mathrm{C}$ by mechanical press.

すると Fig. 2(a)のようになる。この汹は歪み速度 $\dot{\bar{\varepsilon}}=$ $10^{-3} \mathrm{~s}^{-1}$ レベルでの一つの変形抵抗曲面と考えること ができる，等歪みの点を結んだ変形抵抗一温度曲線はそ れぞれの霆みでの温度軟化曲線である.

一方動的試験では試験中に試片の温度が上昇するので その補正をしなければならない。ここでは試片の塑性仕 事の $90 \%$ が熱に変化するとし, 熱伝導については, 動
的試験は加工速度が速いため試験中素材は断熱状態であ ると仮定して，次式によって予測する。

$$
T=T_{0}+\frac{\eta}{\rho C_{p} J} \int_{0}^{\bar{\varepsilon}} \bar{\sigma} d \bar{\varepsilon} \quad \eta=0.9
$$

ここに, $T$ : 温度, $T_{0}$ : 試片の初期温度, $\eta$ : 熱変換率, $\rho$ : 密度, $C_{p}$ : 比熱, $J$ : 熱の仕事当量, $\bar{\sigma}:$ 変形抵抗, $\bar{\varepsilon}:$ 相 当塑性歪み. 各鋼の密度, 比熱は Table 2 に示した值 
Table 2. Material constants for computation of temperature in compression test.

\begin{tabular}{c|c|c|c}
\hline & $\begin{array}{c}\text { Specific heat } C_{p} \\
\left(\mathrm{cal} / \mathrm{g} \cdot{ }^{\circ} \mathrm{C}\right)\end{array}$ & $\begin{array}{c}\text { Mass density } \rho \\
\left(\mathrm{g} / \mathrm{mm}^{3}\right)\end{array}$ & $\begin{array}{c}\text { Heat conductivity } \lambda \\
\left(\mathrm{cal} / \mathrm{mm} \cdot \mathrm{s}^{\circ} \mathrm{C}\right)\end{array}$ \\
\hline $\mathrm{C}$ & 0.11 & $7.83 \times 10^{-3}$ & $1.20 \times 10^{-2}$ \\
$\mathrm{~F}$ & 0.11 & $7.75 \times 10^{-3}$ & $6.44 \times 10^{-3}$ \\
$\mathrm{~A}$ & 0.12 & $8.03 \times 10^{-3}$ & $3.88 \times 10^{-3}$ \\
$\mathrm{DIES}$ & 0.11 & $7.83 \times 10^{-3}$ & $6.10 \times 10^{-3}$ \\
\hline
\end{tabular}

を用いた。これによって予想された温度上昇をもとに動 的試験での変形抵抗曲線を 3 次元表示すると Fig. 2(b) の上うになる，歪みが大きくなるにつれ温度も上昇する ので变形抵抗曲線は試験初期時の温度の位置から温度軸 のプラス方向に向かってずれていく。ここで等歪みの点 を結んだ変形抵抗一温度曲線について新たに $50 \sim 600^{\circ} \mathrm{C}$ まで等温点を $50^{\circ} \mathrm{C} こ ゙ と に$ 線で結び直すと Fig. $2(\mathrm{c})$ の ようになる。この作業により得られた変形抵抗一歪み曲 線を各温度での正味の歪み硬化曲線と考える。 また，こ れによって表された面を歪み速度 $\dot{\bar{\varepsilon}}=15 \mathrm{~s}^{-1}$ レベルで の变形抵抗曲面とする.

以下, この変形抵抗曲面を变形抵抗-歪み平面, 变形 抵抗-温度平面に投影し，それぞれの鋼について歪み硬 化と温度軟化の様子を考察する。

\section{$4 \cdot 2$ 各鋼の歪み硬化特性}

\section{$4 \cdot 2 \cdot 1$ 静的変形抵抗-歪み曲線}

静的試験の場合の変形抵抗一歪み曲線は Fig. 1 の試験 結果である，炭素鋼の場合，試験温度が高くなるにした がい変形抵抗は変化するが, 歪み硬化の程度はこの温度 範囲でほほ同じとなっている。フフェライトステンレス鋼 の場合は, 静的試験では $200^{\circ} \mathrm{C}$ 以上で異常な硬化がみ られるが，30 150 ${ }^{\circ} \mathrm{C}$ までは歪み硬化の程度は同じであ る. 炭素鋼は組織的にみるとフェライト中にパーライト が析出している混合組織ととらえることができるが，歪 み硬化の特性はフェライト単相とほほ同じと考えられ $3^{8)}$.

オーステナイトステンレス鋼の場合は, fcc 金属の場 合にみられる第 II 領域9)が現れていると考えられる. 第 II 領域は転位の集積過程であり，変形抵抗は直線硬 化する，この硬化率は温度，歪み速度の依存性がない． それを過ぎると集積した転位が交差すべりにより脱出し はじめる第 III 領域となる。この領域では変形抵抗は $n$ 乗硬化し温度と歪み速度の影響を受ける．第 III 領域の 開始点は温度が高いほど低歪み側に移る。

\section{$4 \cdot 2 \cdot 2$ 動的变形抵抗一歪み曲線}

動的試験において変形抵抗-歪み一温度曲面を変形抵抗 一歪み平面に投影したものを F1 材について Fig. 3 に示

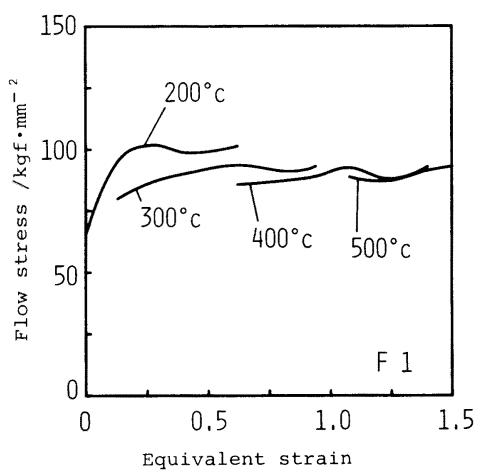

Fig. 3. Modified flow stress-strain curves at each temperature on mechanical press.
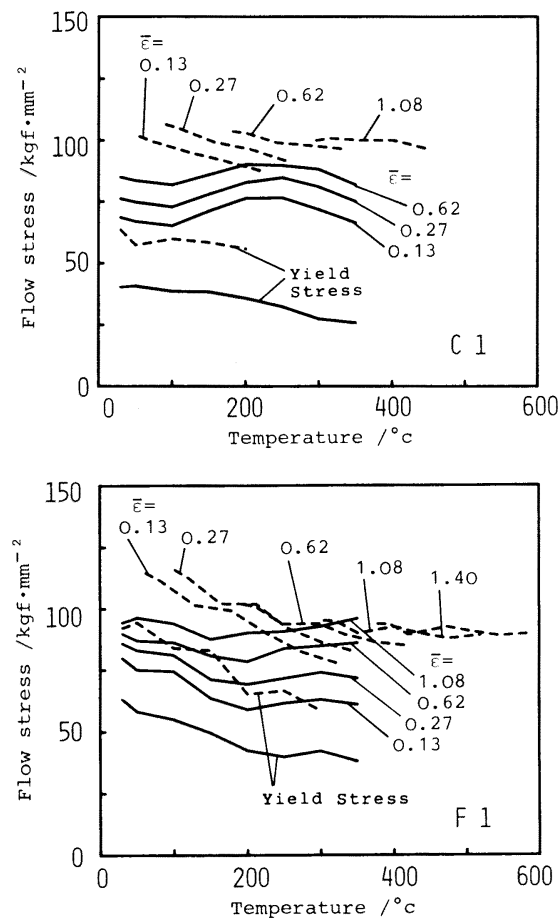

Fig. 4. Flow stress dependence on temperature at each strain by hydraulic press (solid lines) and mechanical press (broken lines).

す。これを見ると静的試験で得られる変形抵抗一歪み曲 線における歪み硬化の傾问とほぼ一致すると見なせる。 他の鋼についても同様の結果が得られている.

\section{$4 \cdot 3$ 炭素鋼，フェライトステンレス鋼の変形抵抗への 温度の影響}

$\mathrm{C} 1$ 材, F 1 材について変形抵抗曲面を変形抵抗一温度 
平面に投影したものを Fig. 4 に示す. 炭素鋼の場合は 静的試験の場合, $200^{\circ} \mathrm{C}$ 付近から变形抵抗が高くなって いる.これは動的歪み時効のためと考えられ, 動的試験 の場合はそのような硬化はみられない。これは歪み速度 が大きいため，高温側に移動したためと考えられる.

フェライトステンレス鋼は静的試験の $200^{\circ} \mathrm{C}$ 以上で 異常な硬化がみられる。これは炭素鋼と同様に動的試験 の場合はこの現象は現れないので動的歪み時効現象に似 ている.

従来ステンレス鋼では動的歪み時効の原因である炭 素, 窒素がクロムと強く結びつくため自由な炭素, 窒素 が少なく, 動的歪み時効は起きないといわれているの で10),この現象は新しいことと考えられる.これにつ いての研究は続報で発表する.

またフェライト鋼の場合は $200^{\circ} \mathrm{C}$ 以上での異常を除 いて考えると炭素鋼に比べて温度による軟化が大きい. これは Fig. 1 に示されるように動的試験におけるF1, F 2 の室温での変形抵抗-歪み曲線の軟化が炭素鋼に比 べて大きいのにも現れている，炭素鋼の温度軟化が小さ いのはセメンタイトの温度軟化率がフェライトと異なる ためと考えられる.

\section{5. 変形抵抗表示式}

以上の特徵をもとにして歪み, 歪み速度, 温度を考虑 した変形抵抗式の表示を試みた。これらの式は数值解析 に使用するのが目的であるため，物理的意味のある表現 ではなく，おもに実験値と合うように形を決定した。し かし，各鋼種の特徵を直感的にとらえられ，単なるパラ メーターの羅列ではないよう努めた.

\section{$5 \cdot 1$ 式表示の基本的考え方}

以下, $\bar{\sigma}:$ 変形抵抗 $\left(\mathrm{kgf} / \mathrm{mm}^{2}\right), \bar{\varepsilon}$ : 相当塑性歪み $(-)$,

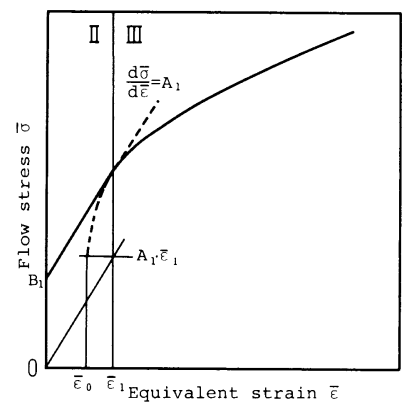

Fig. 5. Schematic illustration of flow stressstrain curves for austenitic stainless steel. $\dot{\bar{\varepsilon}}$ : 歪み速度 $\left(\mathrm{s}^{-1}\right), \quad T$ : 温度 $(\mathrm{K})$, とする.

$5 \cdot 1 \cdot 1$ 炭素鋼およびフェライト鋼の歪み硬化

炭素鋼及びフェライト鋼は次式のような $n$ 乗硬化則 を用いる。

$$
\bar{\sigma}=A+B \cdot \bar{\varepsilon}^{n} \quad \bar{\varepsilon} \geqq 0.002
$$

ここで注意することは, 定数 $A$ は降伏心力†を示すも のではなく，広範井の歪み域でのデー夕を $n$ 乗硬化則 に適合させるためのパラメーターである。この場命の降 伏伈力は式 $(2) に \bar{\varepsilon}=0.002$ を代人することによって 得られる.

$5 \cdot 1 \cdot 2$ オーステナイトステンレス鋼の歪み硬化

オーステナイト鋼の場合は，Fig. 5 に示すように第 II 領域は直線硬化式を用い, 第 III 領域では $n$ 乗硬化 則に従うとした。

$$
\begin{cases}\bar{\sigma}_{1}=A_{1} \cdot \bar{\varepsilon}+B_{1} & \bar{\varepsilon}<\bar{\varepsilon}_{1} \\ \bar{\sigma}_{2}=A_{2}+B_{2} \cdot \bar{\varepsilon} n & \bar{\varepsilon} \geqq \bar{\varepsilon}_{1}\end{cases}
$$

ここに $\bar{\varepsilon}_{1}$ は第 III 領域が始まる歪みである.この遷移 歪み $\bar{\varepsilon}_{1}$ でなめらかに接合するような条件

$$
\begin{aligned}
& \bar{\sigma}_{1}=\bar{\sigma}_{2} \\
& \frac{d \bar{\sigma}_{1}}{d \bar{\varepsilon}}=\frac{d \bar{\sigma}_{2}}{d \bar{\varepsilon}}
\end{aligned}
$$

から式( 4 )を変形すると次式が求められる.

$$
\bar{\sigma}_{2}=A_{1} \cdot \bar{\varepsilon}_{1}+B_{1} \cdot\left(\frac{\bar{\varepsilon}-\bar{\varepsilon}_{0}}{\overline{\varepsilon_{1}}-\bar{\varepsilon}_{0}}\right)^{n}
$$

$\bar{\varepsilon}_{0}$ は式 $(4)$ における $\bar{\varepsilon}=0$ に相当する歪みであるが Fig. 5 のように等めた。すなわち，式（７）に抽正 $=\bar{\varepsilon}_{0}$ のとき, $\bar{\sigma}_{2}=A_{1} \bar{\varepsilon}_{1}$ となるように決めた。この場 合 $\bar{\sigma}_{0}$ は次式により決定される.

$$
\overline{\varepsilon_{0}}=\overline{\varepsilon_{1}}-n \cdot \frac{B_{1}}{A_{1}}
$$

\section{$5 \cdot 1 \cdot 3$ 温度および歪み速度の考慮}

以上の歪み硬化の式を基にそれに温度及び歪み速度の 影響を考慮する.すなわち, 炭素鋼, フェライトステン レス鋼については式( 2 )のパラメーター $A, B$ を, オー ステナイトステンレス鋼については式( 3 ), ( 7 )のパラ メーター $B_{1}, n, \bar{\varepsilon}_{1}$ などを温度, 歪みの関数 $F$ とする. この $F$ の関数形は温度についてはアレニウス型の式

$$
F=a \cdot \exp (c / T)
$$

で表した. パラメーター $a, c$ が歪み速度によって変化 する場合にはさらに $a, c$ に歪み速度の関数にする.

歪み速度の影響については本研究では検討しなかった ので, 静的試験の場合の歪み速度 $\dot{\bar{\varepsilon}}=1 \times 10^{-3} \mathrm{~s}^{-1}$ と

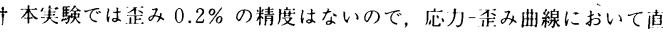
線から離れ始める点を降伏応力とした。たたし, 重回帰分析では計算 上の都合からこの点での塑性胃みを $\bar{\varepsilon}=0.002$ としてデー夕処理を する.
} 
Table 3. Parameters in mathematical models of flow stress determined by the non-linear least squares approximation.

\begin{tabular}{|c|c|c|c|c|c|c|c|c|}
\hline & $\mathrm{C} 1$ & C 2 & & $\mathrm{~F} 1$ & $\mathrm{~F} 2$ & & A 1 & A 2 \\
\hline $\begin{array}{l}A \\
B \\
C \\
n \\
m \\
a \\
h \\
b \\
c\end{array}$ & $\begin{array}{c}-252.5 \\
304.6 \\
161 \\
0.0216 \\
5.74 \\
24.6 \\
4.232 \times 10^{-5} \\
129 \\
533\end{array}$ & $\begin{array}{c}-2.9 \\
37.9 \\
211 \\
0.159 \\
4.22 \\
14.4 \\
3.757 \times 10^{-5} \\
114 \\
595\end{array}$ & $\begin{array}{l}A \\
D \\
C \\
m_{1} \\
m_{2} \\
n_{0} \\
a_{1} \\
h_{1} \\
B_{0} \\
a_{2} \\
h_{2} \\
b \\
c\end{array}$ & $\begin{array}{c}440.4 \\
-428.9 \\
-21.0 \\
4.05 \times 10^{-3} \\
-10.4 \\
0.156 \\
0.134 \\
2.483 \times 10^{-5} \\
54.7 \\
13.5 \\
2.484 \times 10^{-5} \\
70 \\
1107\end{array}$ & $\begin{array}{c}102.8 \\
-104.9 \\
-93.3 \\
2.88 \times 10^{-3} \\
-52.3 \\
0.195 \\
0.349 \\
2.685 \times 10^{-6} \\
43.5 \\
22.6 \\
1.410 \times 10^{-4} \\
70 \\
1094\end{array}$ & $\begin{array}{l}a_{1} \\
c_{1} \\
A \\
a_{2} \\
c_{2} \\
m \\
a_{3} \\
c_{3} \\
m_{1} \\
m_{2}\end{array}$ & $\begin{array}{c}4.61 \times 10^{-2} \\
302 \\
182.3 \\
11.1 \\
226 \\
5.21 \\
0.271 \\
234 \\
-6.98 \times 10^{-2} \\
107\end{array}$ & $\begin{array}{c}4.07 \times 10^{-2} \\
438 \\
177.7 \\
6.16 \\
337 \\
4.63 \\
0.270 \\
162 \\
-6.25 \times 10^{-2} \\
116\end{array}$ \\
\hline
\end{tabular}

し，動的試験の場合を $\dot{\bar{\varepsilon}}=15 \mathrm{~s}^{-1}$ としてデータ処理す

る. $F$ は単純に歪み速度の対数または $m$ 乗に比例する と仮定する.すなわち, 積 $F=C\left(\dot{\bar{\varepsilon}} / \dot{\bar{\varepsilon}}_{0}\right)^{m}$ または和 $F$ $=C+m \cdot \log \left(\dot{\bar{\varepsilon}} / \dot{\bar{\varepsilon}}_{0}\right)$ の形で導入した. ここで, $\dot{\bar{\varepsilon}}_{0}=$ $1 \times 10^{-3} \mathrm{~s}^{-1}$.

また, 各パラメーターが温度により増加減少する場合 は次式のような正規分布関数を利用した。

$F=a \cdot \exp \left\{-h\left(T-T_{C}\right)^{2}\right\}$

ここで, $T_{C}$ は増加のピーク温度である.

$5 \cdot 1 \cdot 4$ パラメーターの決定法

以上のパラメーターは非線形最小二乗法により決定し

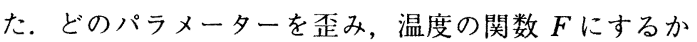
などはいろいろ組合せがあるが, 最小二乗和が小さくな るように選んだ．以下に決定した変形抵抗式を示す．決 定したパラメーターについては, Table 3 に示してある.

\section{$5 \cdot 2$ 変形抵抗式}

$5 \cdot 2 \cdot 1$ 炭素鋼

$$
\begin{aligned}
& \bar{\sigma}=\left\{A+B \cdot \bar{\varepsilon}^{n}+m \cdot \log \left(\frac{\dot{\bar{\varepsilon}}}{\dot{\bar{\varepsilon}}_{0}}\right)\right\} \cdot \exp \frac{C}{T} \\
& +a \cdot \exp \left\{-h\left(T-T_{C}\right)^{2}\right\} \\
& T_{C}=b \cdot \log \left(\frac{\dot{\bar{\varepsilon}}}{\dot{\bar{\varepsilon}}_{0}}\right)+c
\end{aligned}
$$

第 2 項は青熱脆性の項で,これは正規分布を利用した。 青熱脆性のピーク温度は式のような形で温度依存性を考 慮した ${ }^{11)}$ 。この場合, 動的試験でのピークが測定温度 範井以上だったと考えられ, 定数 $b$ は決定することは できなかった. Table 3 に示した $b$ の值は, 最小二乗法 での係数決定の際に動的試験の場合のピーク温度 $T_{C}$ を, C 1, C 2 材共に $T_{C}=1073(\mathrm{~K})^{\dagger 2}$ とおいて便宜上決 めた値であるが, 対象とする温度 $\left(600^{\circ} \mathrm{C}\right.$ 以下), 歪み 速度 $\left(15 \mathrm{~s}^{-1}\right.$ 以下) の範囲の変形抵抗を表現するには これで十分であると考える.

$$
\begin{aligned}
& 5 \cdot 2 \cdot 2 \text { フェライトステンレス鋼 } \\
& \bar{\sigma}=A+B \cdot \bar{\varepsilon}^{n}
\end{aligned}
$$

$$
\begin{aligned}
& +D \cdot\left(\frac{\dot{\bar{\varepsilon}}}{\dot{\bar{\varepsilon}}_{0}}\right)^{m_{1}} \cdot \exp \left\{\frac{C+m_{2} \cdot \log \left(\dot{\bar{\varepsilon}} / \dot{\bar{\varepsilon}}_{0}\right)}{T}\right\} \ldots \\
& n=n_{0}+a_{1} \cdot \exp \left\{-h_{1} \cdot\left(T-T_{C}\right)^{2}\right\} \\
& B=B_{0}+a_{2} \cdot \exp \left\{-h_{2} \cdot\left(T-T_{C}\right)^{2}\right\} \\
& T_{C}=b \cdot \log \left(\frac{\dot{\bar{\varepsilon}}}{\dot{\bar{\varepsilon}}_{0}}\right)+c
\end{aligned}
$$

Fig. 4 より, 歪み速度の大きいときには各歪みでの 温度による軟化の割合は大きいので式( 9 )の $a, c$ に歪 み速度依存性をもたせた。また，静的試験の場合の $200^{\circ} \mathrm{C}$ 以上の硬化を表すため $n$ 值と $B$ の值が正規分布 に従い増大するとした．ただし，この硬化がピークを向 かえた後減少するかは今回の試験では明らかではない が, 最小二乗法での係数決定のため, 便宜的に正規分布 を用いた．同様な理由で，この硬化挙動は動的歪み時効 と同じく高歪み速度では高温側に移動すると仮定した. この場合, $T_{C}$ を F $1, F 2$ 材共に静的試験 $(\dot{\bar{\varepsilon}}=1 \times$ $\left.10^{-3} \mathrm{~s}^{-1}\right)$ のときは $T_{C}=623(\mathrm{~K})$ 付近, 動的試験 $(\dot{\bar{\varepsilon}}$ $\left.=15 \mathrm{~s}^{-1}\right)$ のときは $T_{C}=1273(\mathrm{~K})^{\dagger 2}$ とおいて各係数を 定めた.

$5 \cdot 2 \cdot 3$ オーステナイトステンレス鋼

$$
\begin{aligned}
& \left\{\begin{aligned}
\bar{\sigma}=A \cdot \bar{\varepsilon} & +B+m \cdot \log \left(\frac{\dot{\bar{\varepsilon}}}{\dot{\bar{\varepsilon}}_{0}}\right) \\
& \bar{\varepsilon}<\bar{\varepsilon}_{1} \ldots \ldots \ldots \ldots \ldots \ldots \ldots \ldots \ldots \ldots \ldots \ldots \ldots \ldots \ldots \ldots \ldots \ldots \ldots \ldots \ldots \ldots \ldots
\end{aligned}\right. \\
& \begin{array}{r}
\bar{\sigma}=B \cdot\left(\frac{\bar{\varepsilon}-\bar{\varepsilon}_{0}}{\bar{\varepsilon}_{1}-\bar{\varepsilon}_{0}}\right)^{n}+A \cdot \varepsilon_{1}+m \cdot \log \left(\begin{array}{c}
\dot{\bar{\varepsilon}} \\
\dot{\bar{\varepsilon}_{0}}
\end{array}\right) \\
\quad \bar{\varepsilon} \geqq \bar{\varepsilon}_{1} \ldots \ldots \ldots \ldots \ldots \ldots \ldots \ldots \ldots \ldots \ldots \ldots \ldots \ldots \ldots \ldots \ldots \ldots \ldots \ldots \ldots \ldots \ldots \ldots
\end{array} \\
& \bar{\varepsilon}_{0}=\bar{\varepsilon}_{1}-n \cdot \frac{B}{A} \\
& \bar{\varepsilon}_{1}=a_{1} \cdot \exp \left(\frac{C_{1}}{T}\right)
\end{aligned}
$$

†2これらの温度は実際にはもっと低いであろうが，計算上の都合でひ ずみ速度 $\dot{\bar{\varepsilon}}=15 \mathrm{~s}^{-1}$ では硬化がまったく現れないようにするため高 い温度を設定した。 

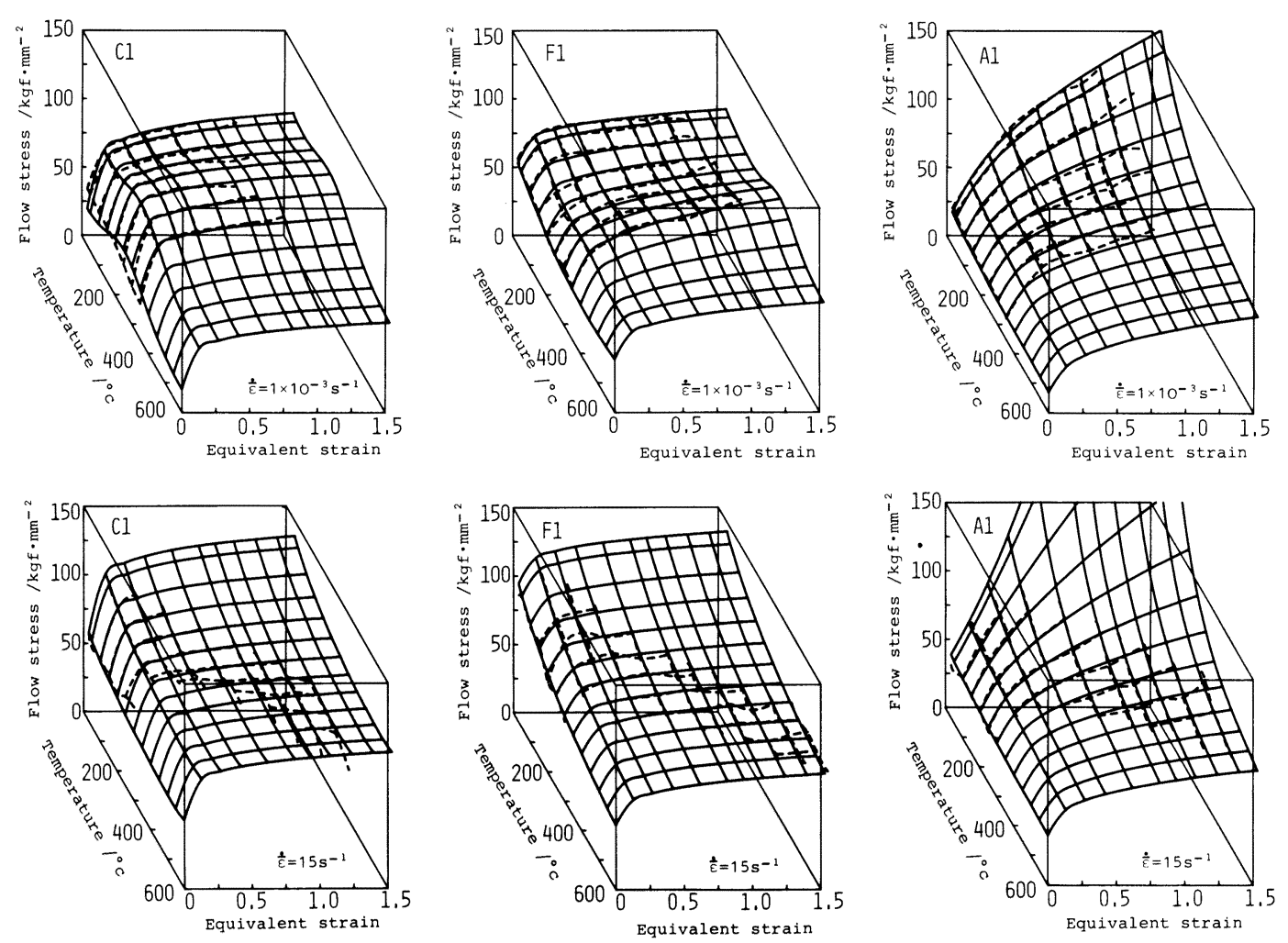

Fig. 6. Comparison of flow stress between calculated from the determined equation (solid lines) and obtained by experiment (broken lines) in various strain, temperature and strain rate.

$$
\begin{aligned}
& B=a_{3} \cdot \exp \left(\frac{C_{2}}{T}\right) \\
& n=a_{3} \cdot\left(\frac{\dot{\bar{\varepsilon}}}{\dot{\bar{\varepsilon}}_{0}}\right)^{m_{1}} \cdot \exp \left\{\frac{C_{3}+m_{2} \cdot \log \left(\dot{\bar{\varepsilon}} / \dot{\bar{\varepsilon}}_{0}\right)}{T}\right\}
\end{aligned}
$$

第 II 領域の直線の傾き $A$ は温度, 歪み速度に存在し ないとし，一定とした。第 III 領域では $n$ 值が温度増加 により減少する。この減少率は歪み速度が大きくなると 小さくなるので式(22)のようにした．第 III 領域の開始 歪み $\varepsilon_{1}$ は温度が増加すると低歪み側に移動するので式 (20)のようにした.

\section{$5 \cdot 3$ 変形抵抗式の 3 次元表示}

以上, 決定した式より計算した值と実験值を C $1, \mathrm{~F} 1$, A1 材について Fig. 6 に示す.よい一致がみられるこ とがわかる. なお， A 1 材については動的試験の場合, $30^{\circ} \mathrm{C}$ 付近での高歪み域のデータが少ないため, その付 近への外挿が大きくはずれていると考えられる.しかし， 高歪み速度の加工.では室温での加工でも変形抵抗曲線は
この歪み範囲に達する前に温度上昇によって高温側にず れていくので実用上問題はない.

動的変形抵抗の曲面は実験で得られた変形抵抗一歪み 曲線を基に，温度上昇を断熱上昇として予想したもので あるが, 動的歪み時効などの異常を除けば静的变形曲面 と類似した結果が得られた。

\section{6. 据込み加工荷重の推算と実験との整合}

ここでは決定した変形抵抗式を実際に数值解析に組み 込み，油圧プレスと機械プレスによる据込み加「の解析 を行った：これはすなわち本実験における端面拘束压縮 試験のシミュレーションでもあり，従って，各鋼の変形 抵抗式の同定が適当ならば，それを組み込んだ解析から 計算した加工荷重と，本実験で得られている荷重とは一 致するはずである．以下でその整命性を調べた。

\section{$6 \cdot 1$ 解析方法の概要}

本解析では, 変形解析に小坂田, 森らの開発した圧縮 性材料の塑性力学に基づいた剛塑性有限要素法 ${ }^{12)}$ を用 


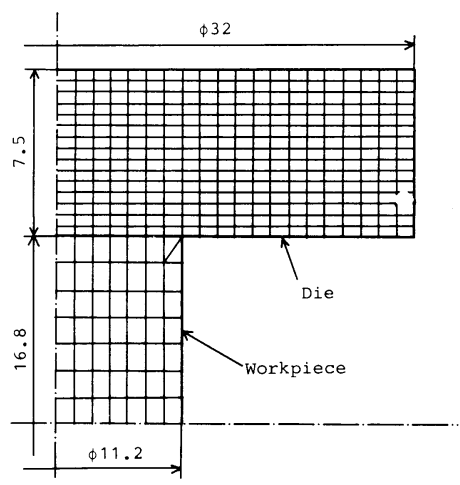

Fig. 7. Mesh of FDM and FEM analyses on workpiece and die.

いた。また，機械プレスでの加」時の温度上昇を考慮す るための熱伝導解析には，差分法を用いた。その際には 剛塑性有限要素法によって計算された塑性变形仕事の $90 \%$ が熱エネルギーに変化するものとし，差分法によっ て熱伝導を計算し温度分布を求めた。この場合，温度を 変形抵抗に处映させるために，変形解析の 1 ステップの 計算が終了するごとに温度の解析をし，その結果から次 のステップの変形抵抗の值を定めた。本実験で同定した 変形抵抗式はその際に用いた。

熱伝導計算で用いた各鋼と:L具の物性值は Table 2 に示してある．また，機械プレスでの加Iについての時 間経過は，ラムの時間一变位実測值から得られた次式を 用い,これより逆算して求めた。

$$
\begin{aligned}
& H=a \cdot \sin ^{2}(b t) \\
& a=74485 \quad b=1.2478 \times 10^{-4}
\end{aligned}
$$

ここに, $H$ : 变位 $(\mathrm{mm}), t$ : 下死点基準の時間 $(\mathrm{ms})$ 要 素分割を Fig. 7 に示す.

\section{$6 \cdot 2$ 解析結果}

Fig. 8 に本解析の荷重の計算値と，端面拘束圧縮に よる実験で得た荷重とを比較した例をC1 について示 す。本解析結果は実験值とよく一致し，これは変形抵抗 式が受当であることを示していると考える.

\section{7. 結言}

炭素鋼，フェライトステンレス鋼，オーステナイトス テンレス鋼の変形抵抗への温度の影響を調べた。この結 果次のことがわかった.

(1)炭素鋼とフェライト鋼は組織が類似しているため歪 み硬化，温度軟化の傾问は基本的に同じである。すなわ ち歪み硬化のぐあいは温度によってほとんど変化しな

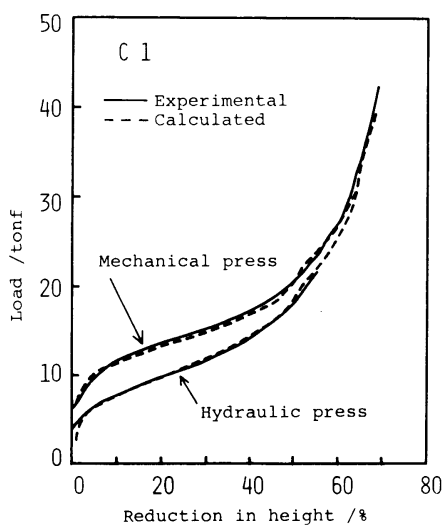

Fig. 8. Upsetting load on hydraulic press and mechanical press.

い.また，両者とも動的歪み時効などの特異な現象が付 加される.

(2)オーステナイト鋼の場命，炭素鋼，フェライト鋼と 比べ結晶構造の違いから歪み硬化, 温度軟化の傾们は大 きく異なる，すなわち，坴温では歪み硬化が著しいが， 温度が高くなるにつれ急激に歪み硬化の割合は小さくな る.

また、これらの特徵を考虑して恋形抵抗式を表した． この変形抵抗式を組み込んだ据込み加门の解析によって 得られた荷重の計算値は，実験結果とよく一致し，整命 性を確認できた。従って，このようにして求めた式はた だちに数值解析に組み込むことができ，冷閒鉔造解析に 有用であると考える。

\section{文献}

1 ）小坂田宏造，小林史朗：塑性と加：，27（1986)，p. 19

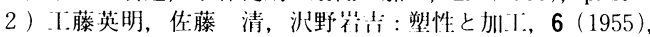
p. 499

3 ) 橋爪 伸: 塑性と加1:, 4 (1963), p. 733

4 ) $K$. Osakada, T. Kawasaki and $K$. Mori : Ann. CIRP, 30 (1981), p. 135

5 ) 加藤 隆, 品川一成: 塑性と加1:, 30 (1989), p. 1030

6 ）戸澤康壽：第 2 回 H中泠間鍛造シンポジゥム論文集 (1987), p. 25

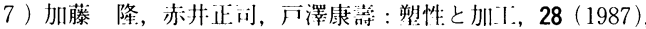
p. 791

8 ）田村今男：ステンレス鐦使覽（長谷川歨義監修）（1973）, p. 118 [日刊 1 - 業新闑社]

9 ) 鈴木唀次: 金属の強さ (1972), p. 20 [アグネ]

10）大矢根守战, 小坡田宏造, 田中H出樹, 宫永聡明: 塑性 と加: : 9 (1968), p. 606

11）大森正信，苦永芳豊: 塑性と加1:, 8 (1967), p. 297

12) $K$. Mori, $K$. Osakada and M. Fukuda : Int. J. Mech. Sci., 25 (1983), p. 775 